DE DE GRUYTER

OPEN

DOI: 10.1515/jolace-2015-0004

\title{
Portfolio-work and its effects on listening comprehension of very young learners
}

\author{
Piri Leeck \\ University of Siegen, Germany \\ leeck@anglistik.uni-siegen.de
}

\begin{abstract}
At elementary school the focus often lies on listening and speaking. While listening comprehension is the basis for learning a new language, children often feel differently about that. Many measure their success in their ability to speak. Some become frustrated, because they initially are not able to express much, not noticing how much they understand already. In my research I tried to find a way to help such children appreciate more what they have achieved so far. Through portfolio-work (self-evaluation and reflection) I wanted them to see what is 'unseen', as well as get them to think about strategies that improve listening comprehension, as the following study report shows.
\end{abstract}

\section{Keywords}

portfolio, listening comprehension, very young learners

"I don't understand a word!" How frustrating for a child who has to learn a new language - and how frustrating also for the teacher. At elementary school level the main focus lies on oral communication, and thus on speaking and listening. Reading and writing are only of secondary importance, appointed a supplementary role by the current curriculum of North Rhine-Westphalia, Germany (see MSW, 2008, p. 8). In the first weeks or months (or for some teachers even years) the implementation of the written form is frowned upon, if not rejected outright. Thus students in grade one and two have only the spoken form to rely on. And even those teachers who confront their students with the written form earlier on do so only sporadically. Thus much of what children accomplish in their first years of learning a language goes undocumented. This in itself is not necessarily bad, but it might be a disadvantage for students who need something more permanent than a functioning class discussion to be reminded of their accomplishments, those who need reassurance of what they have achieved so far, or who want to show their parents what they are able to do already. While speaking can be shown at home, its precursor listening cannot, at least not that easily. This is not the only fundamental difference in listening and speaking (see Wiedmann, 2005, p. 101). Listening develops much faster than speaking (see Kierepka, 2012, p. 7), because it relies on different memory processes than speaking. The skill of listening comprehension uses recognition memory (see Böttger, 2005, p. 27) which is much more effective than the recall memory used for speaking (see ibid.), since it only needs a few important aspects to recognize a complete unit, and depends on analytic skills (see Hecht \& Waas, 1980, p. 122), whereas for speaking every single part of a unit has to be present (see Böttger, 2005, p. 28) and synthetic skills are necessary (see Hecht \& Waas, 1980, p. 122). Piepho (2005, p. 24) shows that it can take a very long time until words and chunks can be produced spontaneously. These structures have to be repeatedly heard and activated before they can be transferred from recognition to recall memory (see Böttger, 2005, p. 28). Thus children might know many words long before they are able to actively use them. 
While this is only natural - in acquiring ones native language there is also an immense lapse of time between understanding and producing language - children (and often parents or even teachers) expect that young learners progress much faster. This can be discouraging for two reasons. For one, listening comprehension at beginners' level does not mean that a learner has to understand every single word. If a child, though, thinks that this is expected of him/her, disappointment will soon set in. Another problem would be if a child focuses on his/her productive skills as the only true indicator of accomplishment in language learning. Either view is unrealistic, but unfortunately not inexistent. In my own small scale study I wanted to investigate possibilities of improving listening comprehension in mixed grades, as I was teaching mixed classes of $3^{\text {rd }}$ and $4^{\text {th }}$ graders (at a time when English lessons were taught in grades three and four only). Within this research project I found that some of my $3^{\text {rd }}$ grade students who claimed not to understand a word actually did understand quite a bit. This intrigued me, and so I focused my next research project on improving students' attitudes toward listening comprehension. My main interest was how to motivate such students, since literature research had brought to my attention that my students were not the only ones who underestimated their skills (see Joiner, 1986; Kolb, 2007; Oxford, 1993), and motivation is said to be one of the main factors for successfully learning a language, the force behind putting forth effort and not giving up (see Elsner, 2010, p. 23; Harmer, 2007, p. 98; Skehan, 1998, p. 38). Students with low self-esteem, such as the one mentioned in the outset, "are likely to give up" (Dörnyei, 2001, p. 87). If, on the other and, students experience success, or perceive what they can do as having accomplished something, they will stay motivated (see Bleyhl, 2005, p. 6; Harmer, 2007, p. 101). Demircioglu even goes a step further and counts recognition of students' successful performance on the teacher's part as part and parcel of raising or maintaining motivation (see 2008, p. 52f.).

Yet listening comprehension is "invisible" (see Rampillon, 1985, p. 69), taking place inside the head, and thus not to be observed directly (see Hermes, 1998, p. 221). It is thus not always obvious to the teacher, and with wrong expectations also to the students, what they have understood. Recognition, though, needs to be based on observable results. These observable results are often actions that students have to perform, or answers given to questions. Yet "[i]n listening there is no simple correlation between the student's answering a question correctly and the level of comprehension achieved by the student" (Flowerdew \& Miller, 2006, p. 184). That is not to say that listening is not active. Underwood's definition highlights this aspect: "Listening is the activity of paying attention and trying to get the meaning from something we hear" (1989, p. 1, P. L. highlights), but for onlookers the one participating in a conversation seems to be more active than the one "just listening".

Rampillon (2000, p. 124) could show that a wide range of possibilities can lead to a student's correctly answering a question, ranging from complete guesswork to thorough understanding. Since the teacher can only assume the cause, be it due to the intonation, facial expression, speed of answering, overall proficiency, etc. but not be sure of what really led to an answer, the student's view can be helpful in rounding out the picture. To get the students view of how well he/she understands classroom discourse individuals could be asked. Yet this is again not permanent, nor is it realistic to get all the students' opinion. Thus a learning diary or portfolio is a suitable alternative, which could also focus the students' attention on how they pay attention. While speaking in class can only be performed by one student at a time (and only when it is the students' turn, not the teacher's or the CD player's - in partner work more than one student can speak, but even in such conversation it is still limited to one of the partners at a time), listening is generally accomplished by all in class, save the ones who do not pay attention. To recognize this accomplishment, a portfolio or learning diary that is worked on by each single student, even by those who did not or could not participate actively, can help to acknowledge everyone's involvement. For students who think of having learned something in the new language in terms of being able to speak only this nicely leads the focus to more basic accomplishments and could thus raise motivation.

Another reason why some students might get discouraged as regards listening comprehension is the "ephemeral nature" (Gómez Martínez, 2009, p. 30) of listening itself. Once something is spoken it is 
usually gone. Comprehending a listening text, or spoken language in general, is thus an act of the moment and nothing that can be looked at later on, or brought home to show the parents. Of course, there are many listening exercises of the listen and tick, listen and connect, listen and circle kind, especially in course books for beginners, which children could show at home. Yet for onlookers it is often not obvious what the real task was (e.g. understanding single words, sentences, or complete texts; the speed or the difficulty of the input, etc.). Speaking (e.g. a poem or little dialogue), reading (e.g. a story book) or written texts (e.g. a self-made pocket book) can generally represent these respective skills much better. Additionally, though there are many of the above-mentioned kinds of tasks, observation has shown that the majority of tasks used at school were rather listen and point ones, which is just as transient as the listening text itself. Again, having something more permanent to document the students' listening skills could help keep up the motivation. A portfolio would be especially helpful in this regard, because it is designed to make progress more obvious, for students work on the same pages at least twice. As someone who is growing usually is less aware of this fact than someone who sees that person only at intervals, so a language learner might not notice how his/her language competence is growing, unless he/she reviews certain aspects from time to time. For the aforementioned two reasons a portfolio (not a learning log or diary, or simple interviews) was chosen as a research-basis. Another reason could also nicely be tied in with portfolio work, as successful listening comprehension has to do with strategies as well.

It is a well-known fact that students, though all receiving roughly the same input, progress at different rates. Differences in success in language learning might be attributed to different learner types or personalities, or even, as hinted at before, different degrees of motivation, where someone who has stronger motivation puts forth more effort (compare Brehm \& Self, 1989, p. 111). On the other hand, there might be students who have already had to learn a foreign language and thus know what to expect and how to go about learning yet another language. This is often connected to (language) learning strategies, "the moment-by-moment techniques that we employ to solve "problems" posed by second language input and output" (Brown, 2007, p. 132). Of course, it is not only children who have had to learn another language who use strategies, but it seems that strategy use is not evenly distributed among all learners, and that it is the more proficient ones who use strategies best (compare Holden, 2002, p. 18; Chamot, 2004, p. 15), above all metacognitive strategies (see Kirsch, 2009, p. 174). There is no agreement in literature as to how strategies should be categorized (see Leeck, 2014, p. 62ff.), but since Chamot's and O'Malley's concept is a widespread one I will stick to it as well.

This already points to an important issue: can less proficient learners or even young children in general be taught strategies? As to the latter part of the question the age-factor certainly does play a role. The prerequisites for being able to use learning strategies develops with age (see Vanderplank, 2008, p. 718f.). The same holds true for memory strategies, which depend on meta-memory (see Holland Joyden \& Kurtz-Costes, 1997, p. 282f.), something that, again, develops with age (see ibid, p. 286f.). On the other hand, children of elementary school age have long been underestimated as to what they can achieve (see Kolb, 2007, p. 309). And studies with older students (see Chan, 2000; 2001; Chau, 2006), who have not been trained in strategy use imply that "the ability to use language learning strategies efficiently do[es] not happen automatically" (Kirsch, 2009, p. 171). Rather, students benefit from strategy training, the weaker ones even more so than the others (see Goh \& Taib, 2006, 222; Chamot, 2004, p. 25).

There is one potential downside, though, that needs to be considered: "Good learners may do certain things because they have the prerequisite abilities to do so. Even if poor learners tried to do these things, they may not be able to and might have to improve their second language skills before they could use these strategies" (Gass \& Selinker, 2001, p. 386). This does not contradict the other sources that say teaching strategies is beneficial, especially for weaker students, but Gass and Selinker emphasize the need to help students discover which strategies work for them in which situation (see ibid; compare Flowerdew \& Miller, 2006, p. 16). This seems important, because there is a wide range of possible strategies (see Leeck, 2014, p. 72), and not every student will use all of them. There might be individual preferences. 
Different tasks might also call for different strategies. In connection with listening comprehension different levels of understanding require different strategies as well. For this it is equally necessary that students know what is expected of them (see Hermes, 1998, p. 226). A look at the curriculum reveals that in grades one and two only basic comprehension is required (see MSW, 2008, p. 14). In literature this is often referred to as 'global' understanding, opposed to 'detailed' understanding. Rampillon (1985, p. 72) divides comprehension even into three different levels (adding one between global and detailed understanding).

While most agree that effective strategy use does not develop automatically, but has to be trained, the question remains how this should be done. In literature differing opinions can be found, ranging from outright warning against overt strategy training, claiming this would turn out "either a turn-off or a distraction" (Holden, 2002, p. 18; see also Bleyhl, 2005, p. 4), to encouraging exactly that: "Strategy training needs to be direct, overt and explicit. [...] Pupils are unlikely to develop strategies, if they do not understand how the teaching activities contribute to their learning" (Kirsch, 2009, p. 183). To find out if direct and overt training can help improve listening comprehension for $2^{\text {nd }}$ graders a portfolio that includes "strategy pages" was chosen, because part of the research was also to investigate how students could become better listeners, and it seems obvious that weaker students do not absorb what better students can do by osmosis. Kolb (2007) also pointed out that portfolio work encompasses more than training students' self-evaluation skills. She highlights the need for recurring reflection phases (see ibid, p. 21).

In summary, it can be said that for the purpose of this research working with a portfolio seemed useful for several reasons: to motivate students the focus should be on what a student has already accomplished, not on the grade he/she might get. Portfolios focus on competences already reached (see MSW, 2009, p. 3), and through repeated work on specific portfolio pages this is even made more obvious. While documenting what a student has accomplished so far can boost his/her motivation, increasing one's skill in listening comprehension certainly does so as well. If teaching strategies help improve these skills then reflecting on strategies in connection with a portfolio should prove useful, too.

There are, of course, many different types of portfolios from which to choose. For this project the European Language Portfolio (Council of Europe, 2007), a course-book independent one, was chosen, mainly because the curriculum for North Rhine-Westphalia suggests it (see MSW, 2008, 23), and because research was done at different schools where different course books were used, which would have made using a course book bound portfolio impractical. (It should be mentioned that there is not one single European Language Portfolio, but all national versions and all versions addressed to different age-groups have to be accredited to be called European Language Portfolio, see MSW, 2009, p. 3). Besides, many course book bound portfolios are custom-made for each unit or set of units of the respective course book (see e.g. PLAYWAY), not allowing to work the same page again at another point in time. Another advantage is that the ELP includes pages for reflecting learning strategies, which was the second focus of this research. As mentioned above, students were asked to reflect on what helps to improve listening comprehension, especially because "teachers frequently expect students to develop their listening capabilities by osmosis and without help" (Mendelsohn, 1984, n.p. in Oxford, 1993, p. 205; compare Brewster, 1991, p. 158), instead of teaching them to listen effectively (see Vandergrift, 2007, n.p. in Edelenbos \& Kubanek, 2009, p. 63). Obviously it is assumed that since we are quite proficient in this skill in our native tongue and often take it for granted (see Hermes, 1998, p. 222), strategies for successful listening can simply be transferred to other languages. Unfortunately this is often not the case (see ibid, p. 223), likely due to the artificial language learning situation in school-like contexts (see Wolff, 1983, p. 291). It thus seems of utmost importance that children be taught basic listening strategies when learning a foreign language at school. It could be argued that this defies the very purpose of starting early, that young learners are not yet able to learn in such a way, or that teaching strategies to beginners is fruitless because they might still lack certain abilities "and might have to improve their second language skills before they could use these strategies" (Gass \& Selinker, 2001, p. 368). Two research questions thus evolved: 
- Does regular portfolio work with its reflection phases improve elementary school students' listening comprehension for the better, also as regards listening strategies?

- Does regular portfolio work improve the self-evaluation skills of such young learners?

This led to the following hypotheses: Assuming benefits, the following is possible:

H1: Regular portfolio work improves listening comprehension competences of even young learner.

H2: Regular portfolio work enables these students to consciously think about and name different

listening strategies.

H3: Regular portfolio work enables these students to use different listening strategies.

H4: Regular portfolio work enables these students to evaluate themselves more accurately.

These hypotheses are not new in a general context. They have already been proven to hold true for older learners (in a wider context, not applying to listening in particular). Yet there might be a certain age-limit, under which it is not possible to train self-evaluation and strategy use. Thus the following hypotheses have to be considered as well:

H5: Despite regular portfolio work young learners show no significant improvement in listening comprehension.

H6: Despite regular portfolio work young learners cannot name different listening strategies.

H7: Despite regular portfolio work young learners cannot use different listening strategies.

H8: Despite regular portfolio work young learners cannot evaluate themselves more accurately.

The differentiation between $\mathrm{H} 2$ and $\mathrm{H} 3$, as well as $\mathrm{H} 6$ and $\mathrm{H} 7$ is an important one to make, because there is a difference in knowing about something and being able to use it. This is supported by Tings (2007, p. 4) who observed that especially younger children often did not notice which strategies they really used, though they could name useful ones.

To find answers to these questions it first needed to be decided on how to collect relevant data. To see whether improvement is not (only) due to natural development, the research design called for a comparison of a so-called treatment-group with a control-group (see Lettau \& Breuer, n.d., p. 4). This is normally done in quantitative research, requiring a large amount of participants (see Winter, 2000, p. 3 ). On the other hand, there was not only the interest in checking improvements at certain intervals, but also in the overall competences of listening and in the reflection phases, which did not take place at prior arranged dates, but as need arose or as they fit into a lesson. This called for a research design of the qualitative kind - ongoing observation. The idea to observe the students listening skills during the regular lessons was based on the following two assumptions: For one, the ability to listen and comprehend is basis of every English lesson, since the better part of the lessons are kept to English. Thus checking comprehension only a few times a year would misrepresent the real picture. Another reason was that listening in "regular" lessons often requires different skills than "pure" listening comprehension in tests. Being present regularly would also allow one to see how students truly perform in comparison to what they evaluate in their portfolio. Especially at the beginning students' own evaluation might not represent what they can really accomplish (see also Friebertshäuser, 1997, p. 371). Furthermore, being in constant attendance also allowed to pick students for interviews based on their performance in class, not at random.

It has to be acknowledged that combining different methods based on different schools of research can make the actual research design complicated if not outright difficult. Quantitative research, such as comparing a treatment-group to a control-group, as mentioned above, usually requires a large amount of participants, where being part of one group or the other depends on coincidence (see Winter, 2000, p. 3 ), whereas qualitative research, such as observation and interviews, uses a much smaller amount of participant, which are usually hand-picked to have a heterogeneous but representative (see Bohnsack, 2005, p. 76) group of "types" (see Winter, 2000, p. 4). In this research there was one decisive difference between the main treatment-group and the control-group. There were children with different handicaps 
(aural perception problems, down-syndrome etc.) in the treatment-group. Thus the results were analyzed with this in mind (in the tables and graphs HA).

For this research a relatively small group of participants was chosen (all in all seven classes at three different schools, two of which could be observed regularly for a year and six months), where one class at each school was used as treatment-group while its parallel class(es) served as control-group. This design enables one not only to observe the students working on their portfolios, but also their reflection phases and how well they could follow the lessons in general. In literature, a combination of such kind is often referred to as triangulation, the idea being that such combining helps to improve the applicability of data, minimizing each research-immanent disadvantage while highlighting its advantages (see Kelle, 2001 , p. 2). Thus, despite the conflict that arose in combining different research methods the advantages were found to outnumber the disadvantages, above all in covering different aspects of a student's skill of listening comprehension.

To fine-tune the research design first a pilot study was started for about six months with three $2^{\text {nd }}$ grade classes all taught by the same teacher. The main study was conducted at two other schools, again starting in the second half of grade two, but continuing until the end of grade three. In short, the research design consisted of the following constituents: a treatment-group that was taught by the same teacher as the control-group (to exclude differences in progress due to different teaching styles or methods) and had not worked with a portfolio before. The ELP (European Language Portfolio) was introduced to the treatment-group and worked on in combination with reflection phases. To compare the ability to evaluate one's own listening skills, the control-group got to evaluate themselves with the same portfolio pages as did their counter-parts in the treatment-group, yet other than that the students of the control-group had not been involved in portfolio work.

A little adjustment had to be made as regards self-evaluation of the students. English sample sentences were read in jumbled order after each student had noted down whether they thought they would understand statements like "Ich kann verstehen wenn mich jemand begrüßt" (Council of Europe, 2007, G-21) (I can understand if someone greets me) or "Ich kann verstehen, wenn mich jemand fragt, welche Hobbys ich habe" (ibid, G-22) (I can understand if someone asks me about my hobbies).

The students in the treatment-group were regularly asked what helped them to understand. Strategies were called 'tips', as this word was known to the students. The treatment-group also worked on the strategy page in the portfolio (see ibid, G-14) and was, towards the end of the research, additionally asked to note down listening comprehension tips that they found most useful. The portfolio self-evaluation pages were worked on after completing one or two units each, amounting to a total of four occurrences.

\section{Results}

In this partially quantitative, partially qualitative study different hypotheses had been investigated. All in all there were four positive and four negative hypotheses each, which will be presented one by one to see which ones are supported by this study.

Regarding performance the following could be observed: at the beginning of my study the situation was quite similar in both groups, certainly due to the teacher teaching the same content with the same methods (except for the portfolio work in the treatment-group). Boys and girls could be found all over the performance-scale. Non-native speakers could also be found on different levels of performance, though most of them were at the lower end (see Tables $1 \& 2$ ).

The first portfolio-check (PF1) showed a small overall advantage of the control-group (see Graph 2), which the teacher had mentioned beforehand. This held true even for the regular students in the treatment-group, if the results of the disabled students are not counted. Yet regular portfolio work soon showed its effects. The treatment-group could improve their performance continually. Of course, that is what is to be expected even in any regular course, but comparisons of both groups brought out that already at the $2^{\text {nd }}$ date (PF2) the treatment-group had caught up with the control-group. If taken by themselves, the regular students even surpassed their counterparts of the control-group. 
Taking a closer look at the results reveals that regular portfolio work helped especially the girls to move up in the performance-scale. Similarly the non-native speakers moved up, though among them there was no distinction between boys or girls. This advantage was kept up during all the following checks, whereas nothing changed in the control-group's original combination.

The improvement in performance that could be observed in the treatment-group is certainly partially due to the improvement of the girls and non-native speakers, though with a reservation. The disabled students (whether boys or girls, whether native speakers or not) could not catch up with their fellow students. The gap between the regular students' performance and that of the disabled ones became wider and wider (see Graph 3).

Hypothesis (1) Regular portfolio work improves listening comprehension competences of even young learner can thus be proven for regular students, especially for girls and for non-native speakers (among whom no difference could be made out between the sexes). For disabled students hypothesis (5) Despite regular portfolio work young learners show no significant improvement in listening comprehension seems to be more adequate.

These results give rise to several questions. The disabled students were left behind by the regular students in all aspects, in the portfolio-work, in regular listening comprehension questions, as well as overall performance during the lessons. Was this due to special demands of the foreign language, or can the same be observed in other lessons as well? Would a different approach to teaching such students a foreign language be of help?

Furthermore, the improvement of girls leads to further research questions: What could be the reason for such an obvious advantage of the girls over the boys? And would the boys catch up later on, or would the girls keep this advantage? It seems that the girls benefitted more from the reflection phases because they did not think as high of their performances as the boys and might thus have accepted help more readily (strategies were not named such, but either tips or help for listening comprehension). On the other hand, it might also be true that boys use different strategies from girls. This would have to be researched in another study. Some studies seem to suggest just this, at least as regards older learners, as Nyikos (2008) found out, while it also has to be mentioned that one of the studies by Ehrmann and Oxford could find no such proof (see ibid, p. 78).

The fact that it was mostly non-native speakers that benefitted from the reflection phases could be traced to the students' experience of already having learned another language. It could be assumed that these students bring with them prerequisites for learning another language that the others do not have yet. If that were true these students would be in what Vygotsky called the Zone of Proximal Development (ZPD) (Vygotsky, 1978 in Pinter, 2006, p. 10f.), a stage at which aid from outside helps to reach the next level. The conversations about strategies might have made the strategies that were subconsciously known to the students obvious and thus helped to improve their performance. Another study would have to investigate this aspect. At least it shows that what was mentioned before holds true for non-native speakers among the regular students: strategy training benefitted the weaker ones even more so than the stronger ones.

Another interesting aspect of this research results was that the otherwise proven disadvantage of Turkish students learning English (see Elsner, 2007; Groot-Wilken et al., 2007) did not hold true for the majority of the students in this study, because most of the Turkish students benefitted from portfolio work and could move up to the upper third of the performance scale. Of course, this was a small-scale study due to the qualitative aspects. Thus the number of Turkish participants it too small to make assertions of universal application. This would have to be tested with a larger amount of participants.

Regarding strategies newer research highlighted how even elementary school children actively work at learning a language (see Kolb, 2007; Tings, 2007), yet mostly this is still done subconsciously. The need to make strategies obvious was hinted at in literature, and in this connection reflection phases were made out as the single most important factor to raise the necessary awareness (see Kolb, 2007). Kolb (ibid.) found that young learners are often underestimated. Others also report that even with elementary school children processes for raising awareness can be used (see Palmer Parreira, 2011, p. 
19), yet this is not due to simple natural development (see Kirsch, 2009, p. 171). Reports from other countries in which autonomous learning is of lesser importance show that e.g. metacognition (see Chan, 2004), as well as readiness to take on responsibility for one's own learning (see Chan, 2001) was only developed rudimentary even among university students, due to a lack of promoting these aspects. On the other hand, a large-scale study suggests that the best time for introducing the portfolio work in elementary school is the $2^{\text {nd }}$ half of the $3^{\text {rd }}$ year (see Drese, 2006). The above mentioned reports and studies were based on work with older elementary school students because at the time given English was taught in grades three and four only in most federal states of Germany. This has changed, and with it the question whether an early start would not include an earlier starting point for portfolio work as well. (This research was purposefully concentrating on grade two instead of one. If there is an age-level under which no benefits can be reaped despite training, this has to be explored step by step.)

To find out which possibilities for development regarding strategy use (for this research confined to listening comprehension) could be expected with even very young students different types of data were made use of: portfolio pages, notes made during the regular lessons and the reflection phases, as well as interviews. This was to serve a two-fold purpose, namely to find out which strategies the students were already aware of and which ones they were made aware of during the reflection phases; secondly to see which strategies the students really used and if these coincided with the self-report of the students.

Comparison of the different data gathered revealed that in either group there were students that used strategies to improve their listening comprehension, independent from whether these strategies were talked about in class or not. How many students in each class used various strategies could unfortunately not be counted statistically. For one, this is due to the fact that not all strategies are observable. Then again, not all students participated equally, some hardly ever at all. It could not be made out whether these students would have used strategies had they be called on to show their comprehension somehow, or whether they did not participate precisely because they were lacking the ability to use strategies.

What was easier to ascertain was whether the students were aware of strategies or not. The first reflection phases showed that the students were to a large extend oblivious of strategies. Even though some of them already used some strategies, hardly anyone could name even one. This was true also for the students of the control-group in which the teacher had included once a reflection phase contrary to the planned research design about nine months after the start of the project. The actual research design did not allow for any further examination of the development of the control-group in this regard, but the treatment-group showed a steady improvement, not only in naming strategies, but also in evaluating their usefulness.

Additionally, analyzing the written documents on strategy use in comparison to the class discussions brought out that many more students could name useful strategies. Only one student could not say whether the reflection phases had helped him and two more said the tips were not useful at all. All three of them were students at the lower end of the performance scale, two of them being handicapped. This highlights what Gass and Selinker $(2001,368)$ supposed, namely that there might be something less successful students have to acquire before they could benefit from any strategy training. On the other hand, the relatively long observation period showed that the majority did actually profit from the reflection phases, because they could not only name strategies, but became aware of which ones were more useful for them and which were not (compare Kolb, 2007).

Hypothesis (2) regular portfolio work enables these students to consciously think about and name different listening strategies can thus be assumed to be generally correct. For some weaker performers the opposite hypothesis (6) despite regular portfolio work young learners cannot name different listening strategies might be more applicable, though.

Hypothesis (3) regular portfolio work enables these students to use different listening strategies can be confirmed only partially, since not all students could be equally well observed in their use of strategies (or lack thereof). Not participating in classroom discourse is certainly not only due to a lack of strategies but also personal factors, lack of interest in the topic at hand or the like. Since some strategies are to be 
observed more easily and more accessible also to the children, a further research project could concentrate on singling out some of these strategies. One of the strategies that was quickly noticed by the students was looking for similarities in German and English, though this was later rejected by many as less useful.

Generally the results showed that children were able to work with a portfolio long before the "ideal time" for introducing it, since the cognitive abilities of the children allowed conscious discussion of strategies and their usefulness. It would thus be important to find out what exactly weaker students need to benefit from these reflection phases as well. Another aspect would be to test this kind of portfolio work already in grade one to see whether $1^{\text {st }}$ graders would also benefit from it, or whether their cognitive development would not allow working with a portfolio appropriately.

A final criterion that was to be investigated within this study was self-evaluation, especially since this requires metacognition which younger elementary students are often said not to have. At least the honesty of the students in self-evaluation is often called into question.

Before portfolio work was initiated the students of the treatment-group (as well as all others observed and found in literature) tended to underestimate somewhat good to excellent performances, while weak performers overestimated what they could do. The control-group in the main study was in this regard an exception, because most of the students in this group overestimated their performance by far.

During the study an interesting development could be observed. At the second self-evaluation the students of the treatment-group evaluated their performance lower than at the first date. This tendency has been described in literature and points to the fact that students first have to become aware of what it means to understand a word/sentence. Many students having to estimate their performance the first time equate having covered a topic in class with knowing the words (see Kolb, 2008, p. 202). As time went by, though, the students learned to evaluate themselves more accurately. This was first observed among the regular students (at the $3^{\text {rd }}$ date), yet at the last date (PF4) even the disabled students could evaluate themselves more realistically. A comparison with the control-group highlights the influence of the portfolio work. Whereas the students of the treatment-group had learned to evaluate their performance the students of the control-group still overestimated what they were able to do. This goes in line with earlier studies done with a little bit older children that showed how portfolio work helps to build up language learning awareness and strategy awareness only if accompanied by regular reflection phases (see Kolb, 2007). The fact that even disabled students, who could not improve their performance, had learned to evaluate themselves more realistically equally supports earlier studies. In them regularity was shown to be more important for successful implementation of reflection phases than a student's IQ (see Pressley et al, 1991; 1992).

Hypothesis (4) regular portfolio work enables these students to evaluate themselves more accurately holds true for regular students as well as for handicapped ones (see Graphs 3,4). It thus supports the general impression that portfolio work is useful and beneficial even for very young learners.

At the outset it was mentioned that while the focus of learning English at elementary school lies on listening and speaking, most students would think of learning a new language only in terms of being able to speak that new language. Some might get frustrated, if expressing themselves in that language might not work as they would hope. This research was designed to make students aware of what they could already accomplish, as well as ways of improving their listening comprehension. The results of the study point to a clear benefit of using portfolio and reflection phases in a combined portfolio work to support students, though it also raised some questions. One that was not mentioned in this study report is the time factor, though the results seem to justify any time spent on additional aspects. There are also many more benefits that could not be mentioned in this short study report, yet I invite all elementary school teachers to start early and introduce portfolio work even in beginners' lessons of English (and any other foreign language). 


\section{References}

Bleyhl, W. (2005). Fremdsprachenlernen - „gesteuert" oder nach den Prinzipien des Muttersprachenerwerbs? PRAXIS Fremdsprachenunterricht 3, 2-7.

Bohnsack, R. (2005). Standards nicht-standardisierter Forschung in den Erziehungs- und Sozialwissenschaften. Zeitschrift für Erziehungswissenschaft (8), Beiheft 4, 63-81.

Böttger, H. (2005). Englisch lernen in der Grundschule. Bad Heilbrunn: Klinkhardt.

Brehm, J. W. \& Self, E. A. (1989). The Intensity of Motivation. Annual Review of Psychology, 40, 109-131.

Brewster, J. (1991). Listening and the young learner. In Brumfit, C., Moon, J. \& Tongue, R. (Eds.), Teaching English to Children. From Practice to Principle (pp. 158-177). London: Harper Collins Publisher.

Chamot, A. U. (2004). Stand der Forschung zum Einsatz von Lernstrategien im Zweit- und Fremdsprachenerwerb. In Barkowski, H. \& Funk, H. (Eds.), Lernerautonomie und Fremdsprachenunterricht (pp. 2-35). Berlin: Cornelsen.

Chan, V. (2000). Fostering learner autonomy in an ESL classroom. TESL Canada Journal, 18(1), 75-86.

Chan, V. (2001). Readiness for learner autonomy: what do our learners tell us? Teaching in Higher Education, 6(4), 500-518.

Chan, W. M. (2004). Lernerautonomie und die metakognitive Entwicklung - Argumente für einen Perspektivenwechsel. In Barkowski, H. \& Funk, H. (Eds.), Lernerautonomie und Fremdsprachenunterricht (pp. 109-126). Berlin: Cornelsen.

Chau, J. (2006). Portfolios for learning. The ternary hierarchy of reflection and feedback. Modern English Teacher, 16(2), 35-39.

Council of Europe (2007). Europäisches Portfolio der Sprachen. Grundportfolio: akk. Modell Nr. 90.2007. Herausgegeben von den Ländern Berlin, Bremen, Hessen, Nordrhein-Westfalen als Ergebnis des BLK-Verbundsprojekts „Sprachen lehren und lernen als Kontinuum“ 2007.

Demircioglu, J. (2008). Englisch in der Grundschule. Auswirkungen auf Leistungen und Selbstbewertung in der weiterführenden Schule. Berlin: Logos Verlag Berlin GmbH.

Dörnyei, Z. (2001). Motivational strategies in the language classroom. Cambridge: Cambridge University Press.

Drese, K. (2006). Das Portfolio im Fremdsprachenunterricht der Grundschule - Erfahrungen mit „Mein Sprachenportfolio“. In Schlüter, N. (Ed.), Fortschritte im frühen Fremdsprachenlernen. Ausgewählte Tagungsbeiträge Weingarten 2004 (pp. 27-33). Berlin: Cornelsen.

Edelenbos, P. \& Kubanek, A. (2009). Gute Praxis im Fremdsprachen-Frühbeginn. Braunschweig: Westermann.

Elsner, D. (2010). Englisch in der Grundschule unterrichten. Grundlagen, Methoden, Praxisbeispiele. München: Oldenbourg Schulbuchverlag GmbH.

Flowerdew, J. \& Miller, L. (2006). Second Language Listening. Theory and Practice. New York: Cambridge University Press.

Friebertshäuser, B. (1997). Interviewtechniken - ein Überblick. In Friebertshäuser, B. \& Prengel, A. (Eds.), Handbuch Qualitative Forschungsmethoden in der Erziehungswissenschaft (pp. 371-395). Weinheim: Juventa.

Gass, S. M. \& Selinker, L. (2001). Second Language Acquisition. An Introductory Course. Mahwah, N.J.: Lawrence Erlbaum.

Goh, C. \& Taib, Y. (2006). Metacognitive instruction in listening for young learners. ELT Journal, 60(3), 222-232.

Gómez Martínez, S. (2009). Tune in. Modern English Teacher, 18(1), 30-32.

Groot-Wilken, B., Engel, G., \& Thürmann, E. (2007). Listening and Reading Comprehension. Erste Ergebnisse einer Studie zu Englisch ab Klasse 3 an nordrhein-westfälischen Grundschulen. forum schule, 1, 35-37.

Hecht, K. \& Waas, L. (1980). Englischunterricht konkret. Linguistische und didaktische Grundlagen, Stundentypen, Übungsformen. Donauwörth: Auer. 
Hermes, L. (1998). Hörverstehen. In Timm, J.-P. (Ed.), Englisch lernen und lehren. Didaktik des Englischunterrichts (pp. 221-228). Berlin: Cornelsen.

Holden, B. (2002). Listen and learn. English Teaching Professional, 23(April), 18-20.

Holland Joyner, M. \& Kurtz-Costes, B. (1997). Metamemory development. In Cowan, N. (Ed.), The Development of memory in childhood (pp. 275-300). Hove East Sussex: Psychology Press.

Joiner, E. (1986). Listening in the foreign language. In Wing, B. H. (Ed.), Listening, Reading, and Writing: Analysis and Application (pp. 43-70). Middlebury: Northeast Conference on the Teaching of Foreign Languages.

Kelle, U. (2001). Sociological Explanations between Micro and Macro and the Integration of Qualitative and Quantitative Methods. Retrieved from http://www.qualitative-research.net/fqs-texte/1-01/101kelle-e.htm

Kierepka, A. (2012). Early Birds. Anfangen mit Englisch - am besten schon in Klasse 1. Grundschule Englisch, 40, 4-9.

Kirsch, C. (2009). Teaching Foreign Languages in the Primary School. London: Continuum International Publishing Group.

Kolb, A. (2007). Portfolioarbeit. Wie Grundschulkinder ihr Sprachenlernen reflektieren. Tübingen: Gunter Narr Verlag.

Kolb, A. (2008). "Da können wir wissen, was wir wissen." Wie Kinder ihr sprachliches Können einschätzen. In Grau, M. \& M. K. Legutke (Eds.), Fremdsprachen in der Grundschule. Auf dem Weg zu einer neuen Lern- und Leistungskultur (pp. 194-210). Frankfurt a. M.: Grundschulverband Arbeitskreis Grundschule e.V.

Leeck, P. (2014). Portfolioarbeit und ihre Auswirkung auf das Hörverstehen sehr junger Englischlerner. Aachen: Shaker Verlag.

Lettau, A. \& Breuer, F. (o. D.). Kurze Einführung in den qualitative-sozialwissenschaftlichen Forschungsstil. Retrieved from www.psy.uni-muenster.de/imperia/md/content/psychologie _institute_3/ae_breuer/publikationen/alfb.pdf.

Ministerium für Schule und Weiterbildung des Landes Nordrhein-Westfalen (2008). Lehrplan Englisch. Frechen: $\quad$ Ritterbach Verlag. Retrieved from http://www.standardsicherung.schulministerium.nrw.de/lehrplaene/upload/klp_gs/GS_LP_E.pdf

Ministerium für Schule und Weiterbildung (2009). Europäisches Portfolio der Sprachen, Grund- und Aufbauportfolio. Handreichungen für Lehrerinnen und Lehrer. Retrieved from http://www.schulbuchzentrum-online-de/suche/artikelansicht.xtp?id=978-3-425-72160-6

Nyikos, M. (2008). Gender and good language learners. In Griffiths, C. (Ed.), Lessons from Good Language Learners (pp. 73-82). Cambridge: Cambridge University Press.

Oxford, R. L. (1993). Research Update on Teaching L2 Listening. System 21(2), 205-211.

Palmer Parreira, S. (2011). Who's in the Family? Den Lernstand im Hörverstehen kontinuierlich überprüfen. Grundschule Englisch, 36, 18-21.

Piepho, H.-E. (2005). Individuelle Lernfortschritte beim Englisch lernen in der Grundschule. In Edelhoff, C. (Ed.), Englisch in der Grundschule und darüber hinaus - Eine praxisnahe Orientierungshilfe (pp. 2433). Frankfurt a.M.: Diesterweg.

Pinter, A. (2006). Teaching young language learners. Oxford: Oxford University Press.

Pressley, M., Gaskins, I. W., Cunicelli, E. A., Burdick, N. J., Schaub-Matt, M., Lee, D. S., \& Powell, N. (1991). Strategy instruction at Benchmark School. Learning disability Quarterly, 14, 19-48.

Pressley, M., Schuder, T., Bergman, J. L., \& El-Dinary, P. B. (1992). A researcher-educator collaborative interview study of transactional comprehension strategies instruction. Journal of Educational Psychology, 84, 231-246.

Rampillon, U. (1985). Lerntechniken im Fremdsprachenunterricht. München: Max Hueber Verlag.

Rampillon, U. (2000). Selbstevaluation als Auslöser konstruktiver Lernprozesse. In Wendt, M. (Ed.), Konstruktion statt Instruktion. Neue Zugänge zu Sprache und Kultur im Fremdsprachenunterricht (pp. 119-140). Frankfurt a. M.: Peter Lang GmbH. 
Skehan, P. (1998). A Cognitive Approach to Language Learning. Oxford: Oxford University Press.

Tings, N. (2007). Der Aufbau von Strategien beim Hörverstehen. Braunschweig: Westermann. Retrieved from http://www.westermann.de/download/grundschule/gs_englisch/didaktik/didaktik.xtp

Underwood, M. (1989). Teaching Listening. London: Longman.

Vanderplank, R. (2008). The Significance of First Language Development in Five to Nine Year Old Children for Second and Foreign Language Learning. Applied Linguistics, 29(4), 717-722.

Wiedmann, T. (2005). Lernstandsbeobachtungen im Englischunterricht der Grundschule Klasse 1/2. In Edelhoff, C. (Ed.), Englisch in der Grundschule und darüber hinaus - Eine praxisnahe Orientierungshilfe (pp. 98-103). Frankfurt a.M.: Diesterweg.

Winter, S. (2000). Quantitative vs. Qualitative Methoden. Retrieved from http://imihome.imi.unikarlsruhe.de/nquantitative_vs_qualitative_methoden

\section{Contact}

Dr. Piri Leeck

Fakultät I, Philosophische Fakultät

Didaktik der englischen Sprache

University of Siegen, Adolf-Reichwein-Str. 2

57068 Siegen, Germany

leeck@anglistik.uni-siegen.de

\section{Appendix}

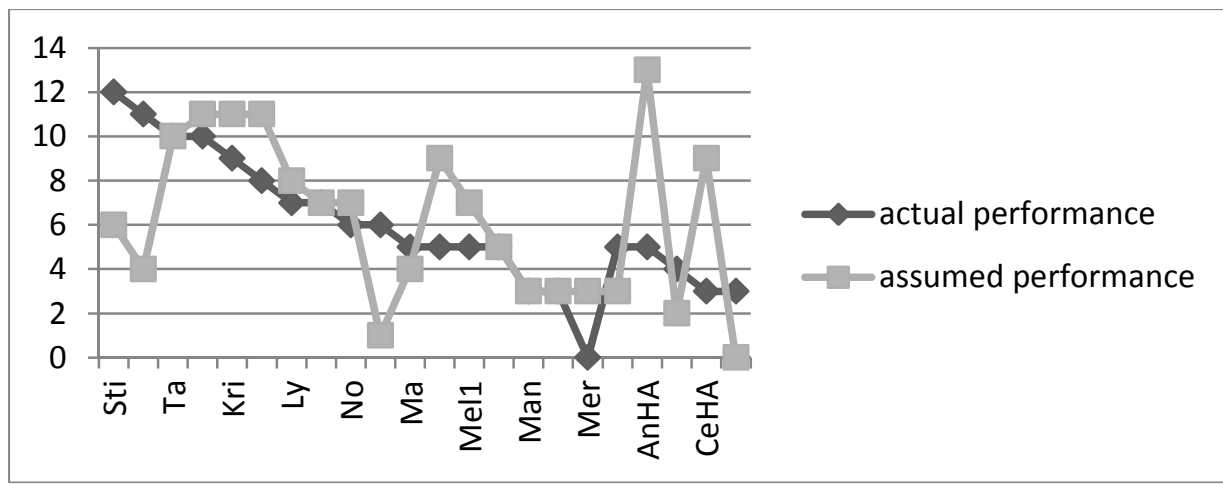

Graph 1: Comparison of assumed and actual performance in listening comprehension of treatment-group 2a, PF1, 04.05.2011 


\section{Comparison Mean 2a and 2c PF1}

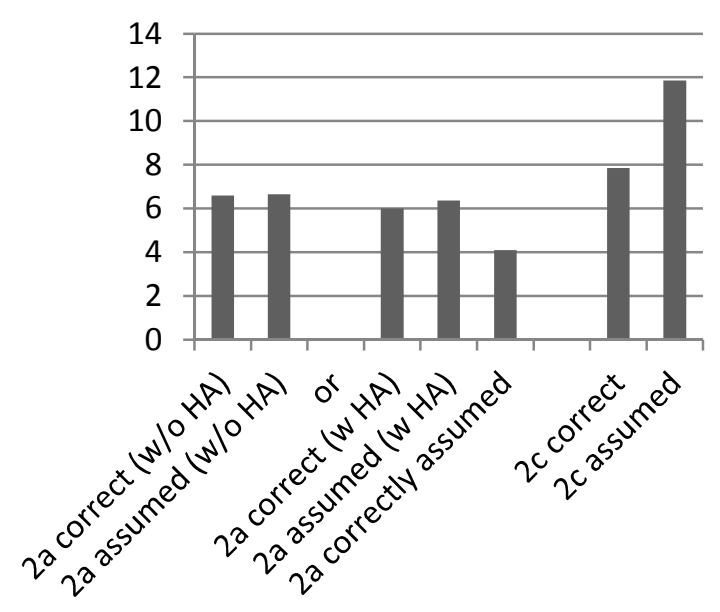

points reached out of 14

Graph 2: Comparison of Mean of both groups; first portfolio evaluation PF1

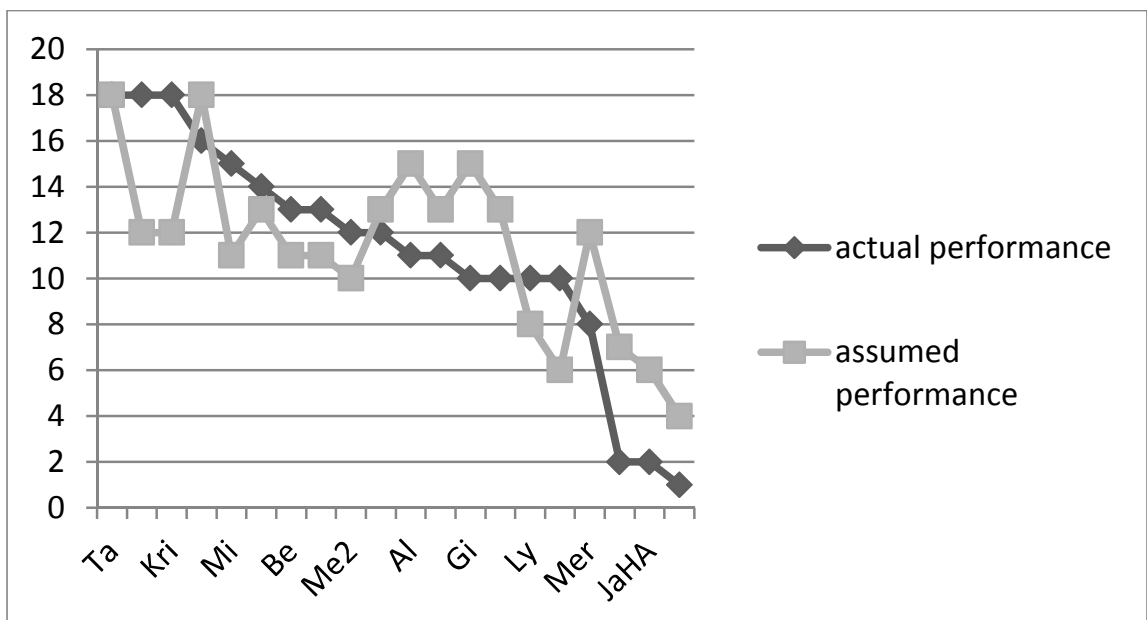

Graph 3: Comparison of assumed and actual performance in listening comprehension of treatment-group 3a, PF4, 06.06 .2012 


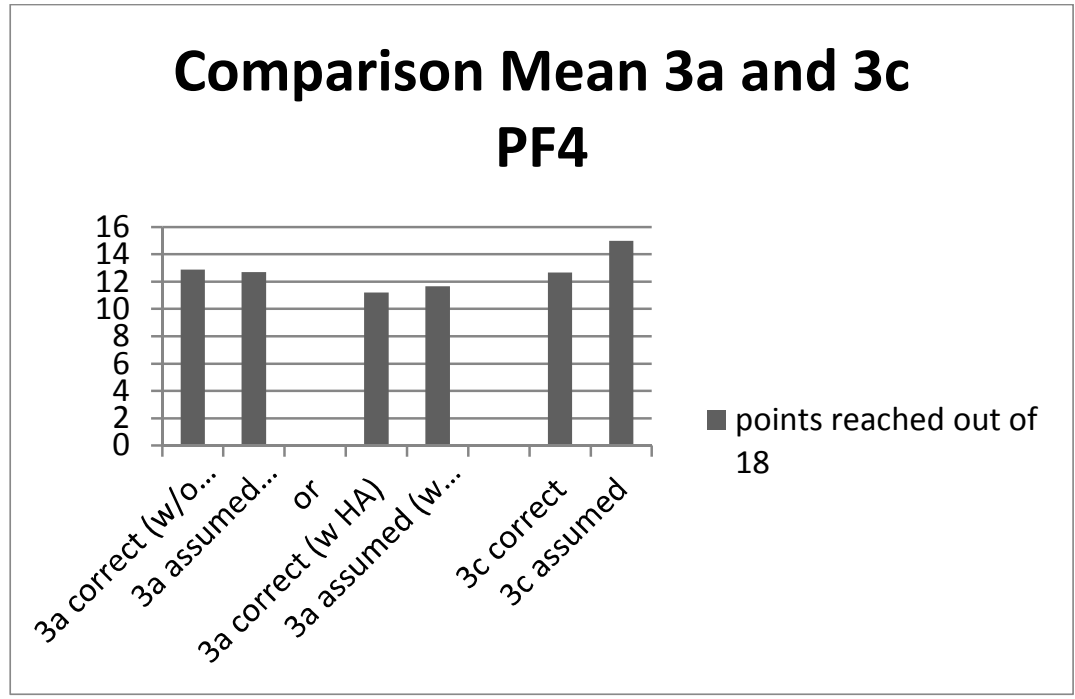

Graph 4: Comparison of Mean of both groups; last portfolio evaluation PF4)

\begin{tabular}{|c|c|c|c|c|c|c|c|c|c|c|c|c|c|c|c|c|c|c|c|c|c|c|}
\hline $\begin{array}{l}\mathrm{PF} \\
1 \\
\end{array}$ & $\mathrm{f}$ & $\mathrm{m}$ & $\mathrm{f}$ & $\mathrm{m}$ & $\mathrm{f}$ & $\mathrm{f}$ & $\mathrm{m}$ & $\mathrm{m}$ & $\mathrm{f}$ & $\mathrm{m}$ & f & $\mathrm{m}$ & f & $\mathrm{f}$ & $\mathrm{m}$ & $\mathrm{m}$ & f & $\begin{array}{l}\mathrm{f} \\
*\end{array}$ & $\begin{array}{l}\mathrm{m} \\
*\end{array}$ & $\begin{array}{l}\mathrm{m} \\
*\end{array}$ & $\begin{array}{l}\mathrm{f} \\
*\end{array}$ & $\mathrm{~m}^{*}$ \\
\hline PF2 & $\mathrm{f}$ & $\mathrm{f}$ & $\mathrm{f}$ & $\mathrm{f}$ & $\mathrm{f}$ & $\mathrm{f}$ & $\mathrm{f}$ & $\mathrm{m}$ & $\mathrm{m}$ & $\mathrm{m}$ & $\mathrm{m}$ & $\mathrm{m}$ & $\mathrm{m}$ & $\mathrm{f}$ & $\begin{array}{l}\mathrm{m} \\
*\end{array}$ & $\begin{array}{l}\mathrm{m} \\
*\end{array}$ & $\begin{array}{l}\mathrm{f} \\
*\end{array}$ & $\begin{array}{l}\mathrm{m} \\
*\end{array}$ & & & & \\
\hline PF3 & $\mathrm{f}$ & $\mathrm{f}$ & $\mathrm{f}$ & $\mathrm{f}$ & $\mathrm{f}$ & $\mathrm{f}$ & $\mathrm{m}$ & $\mathrm{m}$ & $\mathrm{m}$ & $\mathrm{m}$ & $f$ & $\mathrm{~m}$ & $\mathrm{~m}$ & $\mathrm{f}$ & $\mathrm{f}$ & $\mathrm{m}$ & $\begin{array}{l}\mathrm{m} \\
*\end{array}$ & $\begin{array}{l}\mathrm{m} \\
*\end{array}$ & $\begin{array}{l}\mathrm{m} \\
*\end{array}$ & & & \\
\hline PF4 & $\mathrm{f}$ & $\mathrm{f}$ & $\mathrm{f}$ & $\mathrm{f}$ & $\mathrm{f}$ & $\mathrm{f}$ & $\mathrm{m}$ & $\mathrm{m}$ & $\mathrm{f}$ & $\mathrm{f}$ & $\mathrm{m}$ & $\mathrm{m}$ & $\mathrm{m}$ & $\mathrm{m}$ & $\mathrm{m}$ & $\mathrm{m}$ & $\mathrm{f}$ & $\begin{array}{l}\mathrm{m} \\
*\end{array}$ & $\begin{array}{l}\mathrm{m} \\
*\end{array}$ & $\begin{array}{l}\mathrm{m} \\
*\end{array}$ & & \\
\hline
\end{tabular}

Table 1: treatment-group, analysis of performance in portfolio work according to sex and native tongue; $\mathrm{f}=$ female, $\mathrm{m}=$ male; ${ }^{*}=$ disabled student; grey = non-native speaker

\begin{tabular}{|l|c|c|c|c|c|c|c|c|c|c|c|c|c|c|c|c|c|c|c|c|c|c|c|}
\hline PF1 & m & f & m & - & m & m & f & m & f & f & m & m & f & f & m & f & m & f & f & m & m & m & m \\
\hline PF2 & m & f & f & m & f & f & m & m & m & f & m & m & f & m & m & m & f & f & f & m & m & f & \\
\hline PF3 & m & m & f & f & m & m & m & m & f & m & f & m & m & f & - & m & - & m & - & & & & \\
\hline PF4 & m & m & m & f & m & m & f & m & m & f & f & m & m & m & f & - & m & f & f & f & f & m & \\
\hline
\end{tabular}

Table 2: control-group, analysis of performance in portfolio work according to sex and native tongue

Note: For the graphs (see graphs 1 and 3 in this article) the best performance was placed on the left side, getting lower as one proceeds from left to right. This pattern was kept for tables 1 and 2 . The tables thus show that at the first date (PF 1) girls and boys were evenly distributed among all levels of performance in both groups. Similarly, children with migration-background could be found all over the distribution scale. The treatment-group shows a different pattern from PF2 onward, showing the effects of portfolio work. There are no similar changes of pattern in the group without portfolio work. 